\title{
T.I. Гриджук
}

\section{СТАН ПЕРОКСИДНОГО ОКИСНЕННЯ ЛІПІДІВ ТА СИСТЕМИ АНТИОКСИДАНТНОГО ЗАХИСТУ ПРИ МЕДИКАМЕНТОЗНО- ІНДУКОВАНИХ УРАЖЕННЯХ ПЕЧІНКИ У ХВОРИХ НА ХРОНІЧНИЙ ЛІМФОЛЕЙКОЗ}

ДВНЗ «Івано-Франківський національний медичний університет»

Резюме. У статті проведено аналіз впливу хіміотерапії на функціональний стан печінки у хворих на хронічний лімфолейкоз. Установлено формування диференційованих типів медикаментозно-індукованих уражень печінки залежно від особливостей цитостатичної терапії. Доведено зростання інтенсивності пероксидного окиснення ліпідів та напруження антиоксидантного

Вступ. На сучасному етапі розвитку медичної науки медикаментозно-індуковані ураження печінки (МІУП) - одна з важливих проблем гепатології. За даними літератури, частота медикаментозних гепатитів становить від $1 \%$ до $28 \%$ від усіх побічних реакцій, пов'язаних із медикаментозним лікуванням [6]. Особливої уваги заслуговують МІУП у хворих на хронічний лімфолейкоз (ХЛЛ) та інші гемобластози, адже засоби протипухлинної терапії посідають провідне місце щодо частоти та тяжкості спричинених ними гепатотоксичних реакцій [5].

Незважаючи на високу терапевтичну ефективність препаратів для лікування основного захворювання, використання цитостатиків характеризується несприятливим ефектом, що зумовлений гепатотоксичністю, супресією кісткового мозку та опортуністичною інфекцією [7]. У більшості випадків гострих медикаментозних уражень печінки достатньо відміни препарату, який був причиною їх виникнення. Але у випадку застосування хіміотерапії (XТ) в онкогематологічних хворих, відміна гепатотоксичного препарату несе безпосередню або відстрочену загрозу для життя пацієнта [3].

Однісю 3 основних причин структурнофункціональних порушень гепатоцитів при гемобластозах є синдром ендотоксикозу, який розвивається в результаті пухлинної інтоксикації, приєднання бактеріальних і вірусних інфекцій, а також масивного лізису тканини пухлин у відповідь на уведення протипухлинних препаратів [8]. Слід відзначити, що цитостатики можуть у багато разів підсилювати чутливість до ендотоксину.

Останнім часом увагу дослідників привертають питання ролі молекулярних механізмів в ушкодженні мембран гепатоцитів, а саме роль і місце процесів пероксидного окиснення ліпідів (ПОЛ) та активності антиоксидантної системи організму в даних пацієнтів.

Мета дослідження. Дослідити активність системи ПОЛ - АОЗ у плазмі крові та порушення iii функціонування у хворих на ХЛЛ із медикаментозним ураженням печінки. захисту (АОЗ) в осіб із медикаментозно-індукованими ураженнями печінки на тлі хіміотерапії та наявність кореляційних взаємозв'язків між інтенсивністю цитолізу та вираженістю пероксидного окиснення ліпідів.

Ключові слова: хронічний лімфолейкоз, медикаментозно-індуковані ураження печінки, пероксидне окиснення ліпідів, антиоксидантний захист.

Матеріал і методи. Нами проаналізовано 480 медичних карт хворих на ХЛЛ, які перебували на стаціонарному лікуванні в гематологічному відділенні Івано-Франківської обласної клінічної лікарні та отримували різні курси ХТ. Обстежено 90 осіб, в яких діагностовано МІУП, серед них 54 (60 \%) чоловіки та 36 (40\%) жінок віком від 38 до 74 років. Середній вік хворих становив $54,3 \pm 2,43$ року. Окремо виділено та обстежено 20 здорових осіб, що склали групу порівняння відносно досліджуваних показників, яка була репрезентативна до основної групи за статево-віковими характеристиками. Діагноз ХЛЛ був верифікований згідно з клінічними протоколами надання медичної допомоги хворим зі спеціальності «Гематологія», затвердженими Наказом MO3 України № 647 від 30.07.2010 року. Діагноз МІУП встановлювався експертним шляхом із урахуванням даних анамнезу, результатів клінічного та біохімічного досліджень, а також даних ультразвукового обстеження органів черевної порожнини відповідно до протоколів надання медичної допомоги за спеціальністю "Гастроентерологія” (Наказ МО3 України № 271 від 13.06.2005 р.). За результатами оцінки амбулаторних карт, проявів ураження печінки в обстежених осіб до початку курсів ХТ не було. Негативні скринінгові маркери вірусних гепатитів дозволили виключити вірусне інфікування організму.

Усі пацієнти були рандомізовані на три групи залежно від отриманої XТ: I група - особи, для лікування яких використовували лейкеран (n=25); II група - особи, які отримували схему FC (флударабін + циклофосфан) $(\mathrm{n}=35)$; III група особи, яким застосовували схему СНОР (циклофосфамід, доксорубіцин, вінкристин, преднізолон) $(\mathrm{n}=30)$.

Вираженість синдрому цитолізу оцінювали за активністю аланін- і аспартатамінотрансфераз (АлАТ, АсАТ), вмістом загального білірубіну в сироватці крові. Оцінку синдрому внутрішньопечінкового холестазу проводили з урахуванням активності лужної фосфатази (ЛФ), $\gamma$-глутаміл- 
транспептидази (ГГТП), вмістом прямого білірубіну та ступенем розширення внутрішньопечінкових жовчних проток. Наявність мезенхімальнозапального синдрому верифікували за допомогою тимолової проби, а печінково-клітинної недостатності - за вмістом загального білка в сироватці крові та рівнем протромбінового індексу згідно 3 уніфікованими методиками.

Стан ПОЛ визначали за концентрацією малонового альдегіду (МА) за методом В.Б. Гаврилова в модифікації Е.Н. Коробейнікової [4]. Активність антиоксидантної системи досліджували за вмістом церулоплазміну та насиченістю трансферину залізом за методикою Г.О. Бабенко. Вираженість синдрому метаболічної інтоксикації оцінювали за концентрацією молекул середньої маси (МСМ) у крові скринінг-методом у модифікації Н.I. Габріеляна та ін. [2].

Статистичну обробку отриманих результатів проводили на персональному комп'ютері з використанням комп'ютерної програми STATISTICA6.0 і пакета статистичних функцій програми «Microsoft Excel». Кореляційний аналіз проводили за коефіцієнтом Пірсона $\left(\mathrm{r}_{\mathrm{xy}}\right)$.

Результати дослідження та їх обговорення. Унаслідок аналізу медичних карт стаціонарних хворих встановлено, що застосування ХТ у хворих на ХЛЛ у 18,75 \% випадків призвело до розвитку медикаментозно-індукованих уражень печінки. У всіх обстежених осіб МІУП розвивалися латентно, без епізодів гострого токсичного гепатиту. У 40 \% випадків МІУП характеризувалися безсимптомним перебігом, а ураження печінки виявлялося тільки при біохімічному аналізі крові. Серед клінічних проявів найчастіше траплялися астено-вегетативний синдром (у 54 осіб - $60 \%$ ), гепатомегалія (у 45 осіб - 50 \%), зниження апетиту (у 41 особи - 45,56 \%), тяжкість у правому підребер'ї (у 36 осіб - 40 \%), диспепсичний синдром (у 32 осіб - 35,56\%), спленомегалія (у 30 осіб - 33,33 \%), субіктеричність шкіри та склер (у 23 осіб - $25 \%$ ), дещо рідше - больовий абдомінальний синдром (у 18 осіб - $20 \%$ ), жовтяниця (в 11 осіб - 12,22\%), свербіж шкіри (у 7 осіб 7,78\%).

Нами проведено аналіз впливу основних схем хіміотерапії при ХЛЛ на функціональний стан печінки. Установлено, що використання лейкерану, як базового препарату хіміотерапії, призводило до виникнення в осіб холестатичного типу МІУП, на що вказує зростання вмісту загального білірубіну у два рази $\left(\mathrm{p}_{1}<0,001\right)$, прямого білірубіну - у 2,8 раза $\left(\mathrm{p}_{1}<0,001\right)$, активностей лужної фосфатази - у 2,1 раза $\left(\mathrm{p}_{1}<0,001\right)$ та ГГТП - в 1,5 раза $\left(\mathrm{p}_{1}<0,001\right)$ щодо вихідних показників і клінічно проявлялося, насамперед, субіктеричністю, свербежем шкіри, гепатомегалією, больовим та диспепсичним синдромами.

При аналізі медикаментозного впливу схеми FC на печінкову функцію встановлена наявність гепатоцелюлярного типу МІУП. Підтвердженням цьому стало зростання активності АсАТ - до
$(1,34 \pm 0,5)$ ммоль/л/год $(\mathrm{p}<0,001)$ та АлАТ - до $(1,61 \pm 0,5)$ ммоль/л/год $(\mathrm{p}<0,001)$ та збільшення концентрації загального білірубіну в 1,5 раза $(\mathrm{p}<0,001)$ порівняно зі здоровими особами.

Про розвиток процесів цитолізу та холестазу на тлі використання схеми СНОР (табл.1) свідчило підвищення активностей трансаміназ (АлАТ у 2,14 раза, АсАТ - у 2,6 раза, відповідно), ГГТП (в 1,9 раза) та ЛФ (в 1,75 раза) по відношенню до вихідних показників. Одночасно порушувалася здатність печінки до кон'югації та виділення білірубіну, що супроводжувалося зростанням рівня його в сироватці крові в 1,6 раза $\left(\mathrm{p}_{1}<0,001\right)$. Отже, використання схеми СНОР сприяло виникненню змішаного типу МІУП.

Про розвиток мезенхімально-запального синдрому свідчило збільшення показника тимолової проби на $68,4 \%\left(\mathrm{p}_{1}<0,001\right), 143,6 \%$ $\left(\mathrm{p}_{1}<0,001\right)$ та $115,8 \%\left(\mathrm{p}_{1}<0,001\right)$ у хворих I, II та III груп відповідно порівняно зі значенням аналогічних показників до початку лікування.

Погіршення протеїнсинтезуючої функції печінки у хворих II та III груп в процесі застосування ХТ проявлялося зниженням рівнів загального білка в $1,12\left(\mathrm{p}_{1}<0,05\right)$ та 1,06 раза $\left(\mathrm{p}_{1}<0,05\right)$ відповідно (табл. 1).

При аналізі вмісту продуктів пероксидації ліпідів у хворих на ХЛЛ виявлено, що середній рівень МА підвищувався порівняно з контролем в усіх досліджуваних групах до початку цитостатичної терапії, ймовірно, внаслідок основного захворювання (табл. 2). Водночас використання досліджуваних схем терапії ХЛЛ зумовлювало поглиблення печінкової дисфункції та інтенсифікацію ПОЛ, що проявлялося більш інтенсивним зростанням рівня МА. Зокрема, вміст у крові даного показника був найвищим в обстежених хворих II групи і складав $(6,95 \pm 0,13)$ нмоль/мл, що в 1,9 раза перевищувало вихідні дані $\left(\mathrm{p}_{1}<0,001\right)$. Одночасно рівень МА достовірно збільшувався також у хворих I та III груп в 1,77 і 1,87 раза відповідно $\left(\mathrm{p}_{1}<0,001\right)$.

Активація процесів ПОЛ супроводжувалася напруженням системи АО3, на що вказувало збільшення активності церулоплазміну $(\mathrm{p}<0,01)$ i зменшення насиченості трансферину залізом $(\mathrm{p}<0,05)$ порівняно 3 контрольною групою у всіх досліджуваних групах ще до початку XТ.

Як видно з табл. 2, використання цитостатичної терапії призводило також до підвищення активності церулоплазміну в усіх групах дослідження.

Так, середнє значення даного показника зросло в 1,17 раза $\left(\mathrm{p}_{1}<0,01\right)$ - у I групі хворих, в 1,25 раза $\left(\mathrm{p}_{1}<0,001\right)-$ у II групі та в 1,23 раза $\left(\mathrm{p}_{1}<0,01\right)$ у III групі хворих. Відмічено вірогідне зниження насиченості трансферину залізом в усіх групах паціснтів ( $<0,001)$ (табл.2).

Згідно $з$ джерелами літератури відомо, що активація системи ПОЛ відіграє важливу роль у механізмах пошкодження клітин [1]. Нами встановлено позитивний кореляційний зв'язок серед- 

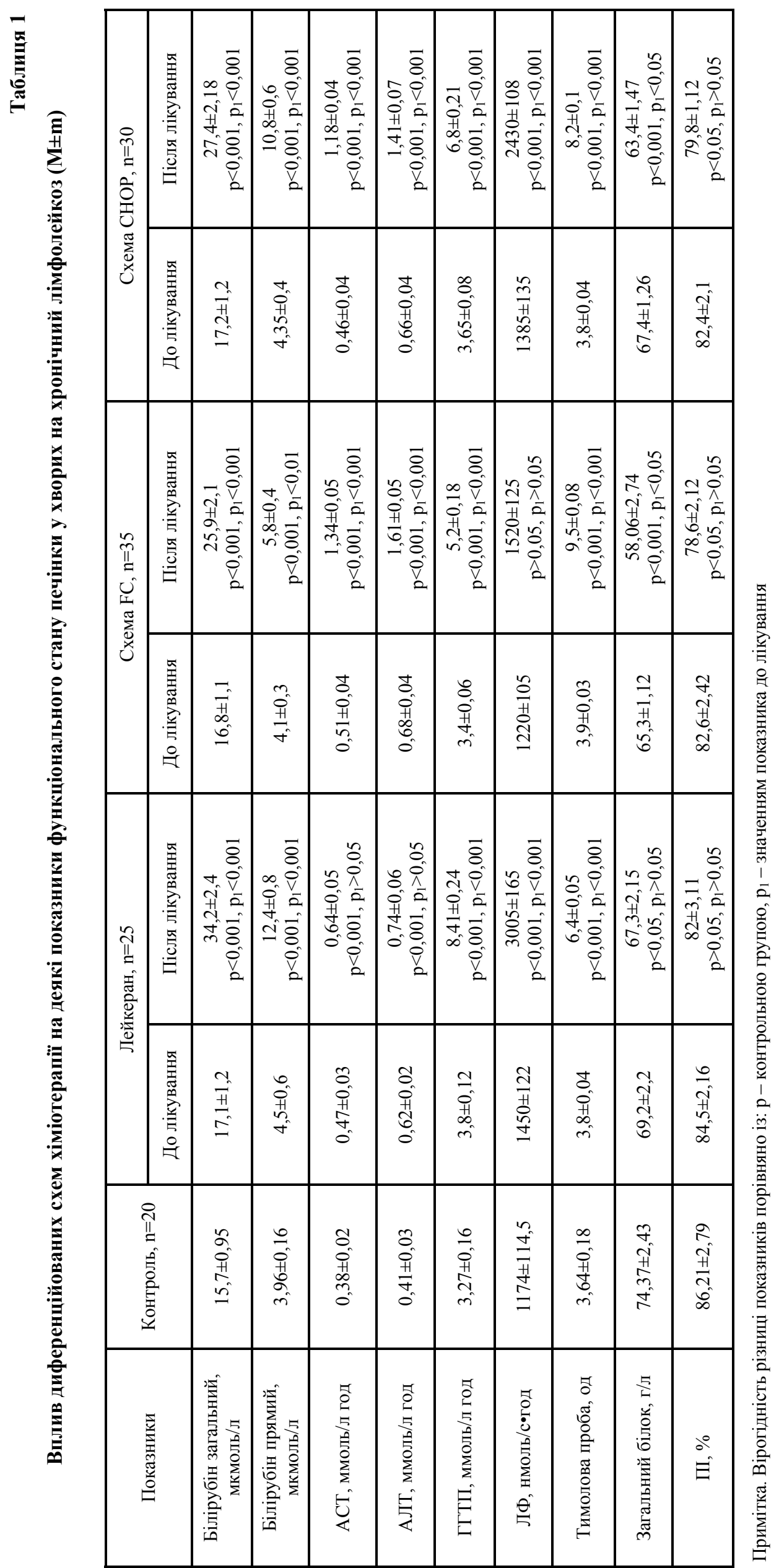
ньої сили між збільшенням активності АлАТ та рівнем МА в усіх досліджуваних групах. Коефіцієнт кореляції (r) між наведеними показниками дорівнював $+0,67(\mathrm{p}<0,01)-$ у I групі, +0,62 $(\mathrm{p}<0,01)$ - у II групі та $+0,65$ в осіб, яким проводили терапію СНОР (III група) (p<0,01). Це свідчить про те, що інтенсивність процесів ПОЛ зумовлює інтенсивність цитолізу гепатоцитів.

При оцінці ендогенної інтоксикації нами встановлено, що у всіх пацієнтів рівень МСМ у сироватці крові істотно підвищився внаслідок застосування ХT. Так, у хворих I групи до лікування середній рівень даного показника дорівнював $(0,31 \pm 0,013)$ ум.од. та істотно збільшився після використання лейкерану до $(0,38 \pm 0,025)$ ум.од. $\left(\mathrm{p}_{1}<0,05\right)$. Застосування схеми FC призводило до зростання МСМ у II групі з $(0,34 \pm 0,025)$ ум.од. до $(0,45 \pm 0,03)$ ум.од. $\left(\mathrm{p}_{1}<0,01\right)$. Значною була вираженість ендогенної інтоксикації у хворих, ХТ яким проводили за допомогою схеми СНОР. Про це свідчить вірогідне збільшення МСМ у III групі до рівня $(0,43 \pm 0,02)$ ум.од. $\left(\mathrm{p}_{1}<0,001\right)$.

Кореляційний аналіз взаємозв'язку між показниками ендогенної інтоксикації та продуктами ПОЛ виявив пряму позитивну кореляційну залежність між рівнями МСМ і МА (коефіцієнт кореляції у I, II, III групах r=0,69; r=0,59; r=0,61 відповідно; $\mathrm{p}<0,01)$, що свідчить про значимість процесів інтенсифікації ПОЛ для оцінки інтенсивності ендогенної інтоксикації при МІУП.

Таким чином, навантаження організму продуктами ПОЛ та напруження АО3 у хворих на ХЛЛ наростає при МІУП та супроводжується процесом метаболічної інтоксикації.

\section{Висновки}

1. Використання хіміотерапії у хворих на хронічний лімфолейкоз призводить до виникнення медикаментозно-індукованих ураженнь печінки, типи яких пов'язані з диференційованими особливостями цитостатичного лікування.

2. Застосування лейкерану призводить до виникнення переважно холестатичного типу, схеми FC - гепатоцелюлярного типу, а схеми CHOP - змішаного типу медикаментозноіндукованих уражень печінки.

3. Виникнення медикаментозно-індукованих уражень печінки на тлі хіміотерапії хронічного лімфолейкозу супроводжується зростанням інтенсивності пероксидного окиснення ліпідів та напруженням антиоксидантного захисту, що проявляється підвищенням рівня малонового альдегіду, церулоплазміну та зниженням насиченості трансферину залізом.

4. Встановлено наявність достовірного прямого кореляційного зв'язку середньої сили між активністю АлАТ та рівнем малонового альдегіду, а також між рівнем малонового альдегіду та концентрацією молекул середньої маси в сироватці хворих на хронічний лімфолейкоз із медикаментозно-індукованими ураженнями печінки.

Перспективи подальших досліджень. Отримані результати дослідження підтверджу- 
ють доцільність пошуку та застосування сучасних ефективних та безпечних засобів з гепатопротекторними, дезінтоксикаційними та метаболічними властивостями у хворих на ХЛЛ як до призначення цитостатичних середників, так і впродовж усього періоду специфічного лікування.

\section{Лiтература}

1. Бондарев Л.С. О проблеме лекарственных гепатитов / Л.С. Бондарев, Н.М. Клыса // Ж. практ. лікаря. 2004. - № 5-6. - С. 16-19.

2. Габриэлян Н.И. Диагностическая ценность определения средних молекул в плазме крови при нефрологических заболеваниях / И.Н. Габриэлян, А.А. Дмитриев, Г.П. Кулаков // Клин. мед. - 1981. - № 10. - С. 38-42.

3. Kim J. An overview of drug-induced liver disease / J. Kim // US Pharm. - 2005. - Vol. 11. - P. 10-21.

4. Коробейникова Э.Н. Модификация определения продуктов перекисного окисления липидов в реакции с тиобарбитуровой кислотой / Э.Н. Коробейникова // Лаб. дело. - 1989. - № 7. - С. 8-10.

5. Marino G. Management of drug-induced liver disease / G. Marino, H.J.Limmerman // Cur. Gastr. Reports. 2007. - Vol. 3. - P. 38-48.

6. Полунина Т.Е. Лекарственные поражения печени / Т.Е. Полунина, И.В. Маев // Гастроэнтерология. 2011. - № 2. - С. 54-60.

7. Скрипник И.Н. Медикаментозный гепатит у онкогематологических больных: патогенетические механизмы и корригирующая роль урсодезоксихолевой кислоты / И.Н. Скрипник, А.В. Невойт, Т.А. Ворошилова: мат. науково-практичної конференції з міжнародною участю [«Хвороби печінки в практиці клініциста»] (Харків, 1-2.III.07). - Харків, 2007. - С. 272-273.

8. Токсичне ураження печінки у пацієнтів з онкологічною патологією (діагностика, лікування) / О.А. Карнабеда, С.М. Ткач, В.Г. Передерій [та ін.] // Клин. онкол. - 2013. - № 1. - С. 125-131.

\section{СОСТОЯНИЕ ПЕРЕКИСНОГО ОКИСЛЕНИЯ ЛИПИДОВ И СИСТЕМЫ АНТИОКСИДАНТНОЙ ЗАЩИТЫ ПРИ ЛЕКАРСТВЕННО-ИНДУЦИРОВАННЫХ ПОРАЖЕНИЯХ ПЕЧЕНИ У БОЛЬНЫХ ХРОНИЧЕСКИМ ЛИМФОЛЕЙКОЗОМ}

\section{Т.И. Гриджук}

Резюме. В статье проведен анализ влияния химиотерапии у больных хроническим лимфолейкозом на функциональное состояние печени. Установлено формирование дифференцированных типов лекарственноиндуцированных поражений печени в зависимости от особенностей цитостатической терапии. Доказан рост интенсивности перекисного окисления липидов и напряжение антиоксидантной защиты (АОЗ) у больных с лекарственно-индуцированными поражениями печени на фоне химиотерапии и наличие корреляционных взаимосвязей между интенсивностью цитолиза и выраженностью перекисного окисления липидов.

Ключевые слова: хронический лимфолейкоз, лекарственно-индуцированные поражения печени, перекисное окисление липидов, антиоксидантная защита.

\section{STATUS OF LIPID PEROXIDATION AND ANTIOXIDANT DEFENCE SYSTEM IN DRUG-INDUCED LIVER DAMAGE IN PATIENTS WITH CHRONIC LYMPHOCYTIC LEUKEMIA}

\section{T.I. Grydzhuk}

Abstract. The paper analyzes the impact of chemotherapy in patients with chronic lymphocytic leukemia in the functional state of the liver.The formation of differentiated types of drug- induced liver damage, depending on the characteristics of cytostatic therapy has been established. The intensity of lipid peroxidation and antioxidant defence stress in patients with drug- induced liver damage on a background of chemotherapy and the presence of correlation relationships between the intensity of cytolysis and severity of lipid peroxidation have been proved.

Key words: chronic lymphocytic leukemia, drug-induced liver damage, lipid peroxidation, antioxidant defence.

SHEE «Ivano-Frankivsk National Medical University»

Рецензент - проф. О.І. Федів
Buk. Med. Herald. - 2014. - Vol. 18, № 2 (70). - P. 24-28

Надійшла до редакції 18.02.2014 року

(C) T.I. Гриджук, 2014 